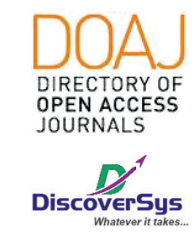

Published by DiscoverSys

\section{Gambaran hasil pemeriksaan faal hemostasis pada penderita Diabetes Melitus tipe-2 (DM-2) di RSUP Sanglah, Bali, Indonesia}

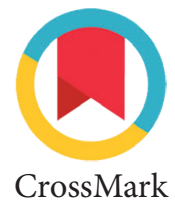

\author{
Nyoman Pramudita, ${ }^{*}$ Ni Kadek Mulyantari ${ }^{2}$
}

\section{ABSTRACT}

Background: Diabetes Mellitus Type II (DM-2) is a type of hyperglycemic state which is related to metabolic disorders caused by mutations in several genes. Faal hemostasis is a function of the body that aims to maintain the blood that has been thinned so that the blood flowing in the veins and could be interfere with blood glucose level. This study aims to describe the faal hemostasis examination in patients with DM-2 in Sanglah Hospital.

Methods: A cross-sectional study was conducted among patients with diabetes mellitus type II (DM-2) who were hospitalized in Sanglah hospital at the period started from January $1^{\text {st }}$ to December $31^{\text {st }}, 2015$. The sample selection were using consecutive sampling with a total of twenty eight samples. Data were analyzed using SPSS version 17 for Windows

Results: The study found that males were predominant in this study (53.6\%). In addition, 51-60 years age group were also predominant (39.3\%), following by history of hypertension (82.1\%), 10-14 seconds of Prothrombin Time (PT) (67.9\%), 30-40 seconds of Activated Partial Thromboplastin Time (APTT) (53.5\%), and bleeding time (BT) $>1.3$ minutes $(67.9 \%)$.

Conclusion: Several faal hemostasis assessments were predominant in patients with DM-2 such as 10-14 seconds of PT, 20-40 seconds of APTT, and bleeding time more than 1.3 minutes.

Keywords: faal hemostasis examination, diabetes mellitus type II, diabetes mellitus

Cite This Article: Pramudita, N., Mulyantari, N.K. 2019. Gambaran hasil pemeriksaan faal hemostasis pada penderita Diabetes Melitus tipe-2 (DM-2) di RSUP Sanglah, Bali, Indonesia. Intisari Sains Medis 10(2): 240-243. D0I: 10.15562/ism.v10i2.392

\title{
ABSTRAK
}

Latar belakang: Diabetes Mellitus tipe II (DM-2) merupakan tipe yang terjadi karena adanya kelainan metabolisme yang disebabkan oleh mutasi pada banyak gen. Faal Hemostasis adalah suatu fungsi tubuh yang bertujuan untuk mempertahankan keenceran darah sehingga darah tetap mengalir dalam pembuluh darah. Tujuan dari penelitian ini adalah untuk mengetahui gambaran hasil pemeriksaan faal hemostasis pada pasien penderita DM-2 di RSUP Sanglah.

Metode: Sebuah studi potong lintang dilakukan pada pasien dengan diabetes mellitus tipe II (DM-2) yang dirawat di Rumah Sakit Sanglah pada periode 1 Januari hingga 31 Desember 2015. Pemilihan sampel menggunakan teknik konsekutig yang melibatkan dua puluh delapan sampel. Data dianalisis menggunakan SPSS versi 17 untuk Windows Hasil: Studi ini menemukan bahwa jenis kelamin laki-laki adalah dominan dalam penelitian ini $(53,6 \%)$. Selain itu, kelompok usia 51-60 tahun juga dominan (39,3\%), diikuti oleh riwayat hipertensi (82,1\%), 10-14 detik Waktu Prothrombin (PT) (67,9\%), 30-40 detik Waktu Tromboplastin Teraktivasi Parsial (APTT) (53,5\%), dan waktu perdarahan $(\mathrm{BT})>1,3$ menit $(67,9 \%)$.
'Pendidikan Dokter Umum, Fakultas Kedokteran, Universitas Udayana, Bali, Indonesia ${ }^{2}$ Departemen Patologi Klinik, Fakultas Kedokteran, Universitas Udayana, RSUP Sanglah, Bali, Indonesia.

\section{*Korespondensi:}

Nyoman Pramudita; Pendidikan Dokter Umum, Fakultas Kedokteran, Universitas Udayana, Bali, Indonesia pramuditanyoman@yahoo.com

Diterima: 31-12-2018

Disetujui: 24-05-2019

Diterbitkan: 01-08-2019
Kata kunci: pemeriksaan faal hemostasis, diabetes mellitus tipe II, diabetes mellitus

Cite Pasal Ini: Pramudita, N., Mulyantari, N.K. 2019. Gambaran hasil pemeriksaan faal hemostasis pada penderita Diabetes Melitus tipe-2 (DM-2) di RSUP Sanglah, Bali, Indonesia. Intisari Sains Medis 10(2): 240-243. D0I: 10.15562/ism.v10i2.392

\section{PENDAHULUAN}

Diabetes Mellitus (DM) menurut Perkeni adalah sekelompok penyakit metabolik yang ditandai dengan hiperglekemia yang terjadi karena gangguan pada sekresi insulin, aksi insulin atau bisa keduanya. ${ }^{1}$ Ketika seseorang menderita DM maka pankreas orang tersebut tidak dapat menghasilkan cukup insulin untuk menyerap glukosa yang diperoleh dari makanan. Hal inilah yang menyebabkan kadar glukosa dalam darah menjadi tinggi akibat timbunan glukosa dari makanan yang tidak dapat diserap dengan baik dan dibakar menjadi energi. Pada umumnya Diabetes Mellitus dibagi menjadi 2 tipe yaitu Diabetes Mellitus tipe I (DM-1) dan Diabetes Mellitus tipe II (DM-2).,

Diabetes Mellitus tipe II (DM-2) adalah kasus yang lebih umum penderitanya dibandingkan 
dengan DM-1. Tahun 2003, WHO memperkirakan 194 juta atau (5,1\%) dari 3,8 milyar penduduk dunia usia 20-79 tahun menderita DM-2, dan diperkirakan pada tahun 2025, penderita DM-2 di seluruh dunia berkisar antara 333 juta orang $(5,4 \%) .^{3}$ Di tahun yang sama International Diabetes Federation (IDF) menyebutkan bahwa prevalensi DM-2 di dunia adalah 1,9\% dan telah menjadikan DM-2 sebagai penyebab kematian urutan ke tujuh di dunia. Berdasarkan catatan organisasi kesehatan dunia tahun 1998, Indonesia menduduki peringkat keenam dengan jumlah penderita DM-2 terbanyak setelah India, Cina, Rusia, Jepang dan Brazil. ${ }^{4}$ Penderita DM-2 di Indonesia semakin meningkat. Hal ini dapat diketahui bahwa pada tahun 1995 terdapat lebih kurang 5 juta penderita DM-2 di Indonesia dengan peningkatan sekitar 230 ribu penderita setiap tahun, sehingga pada tahun 2025 penderita DM-2 di Indonesia diperkirakan akan mencapai 12 juta orang. ${ }^{4}$

Peningkatan tersebut terjadi akibat bertambahnya populasi penduduk usia lanjut dan perubahan gaya hidup, mulai dari pola makan atau jenis makanan yang dikonsumsi sampai berkurangnya kegiatan jasmani. Hal ini terjadi terutama pada kelompok usia dewasa ke atas pada seluruh status sosial-ekonomi. ${ }^{5}$

Pada DM-2 yang tidak terkendali dapat terjadi komplikasi metabolik akut maupun komplikasi vaskuler kronik, baik mikroangiopati maupun makroangiopati. Komplikasi kronis yang dapat terjadi pada Diabetes Mellitus tipe II yang tidak terkendali seperti kerusakan saraf, kerusakan ginjal, kerusakan mata, penyakit jantung koroner, hipertensi, penyakit pembuluh darah perifer, gangguan pada hati, gangguan faal hemostasis, penyakit paru, gangguan saluran cerna, dan infeksi. ${ }^{6}$

Berbagai penelitian observasional dan eksperimental sudah ada yang membuktikan bahwa hiperinsulinemia, hiperglikemia, dan resistensi insulin yang sudah terjadi sejak lama dapat meningkatkan aktivitas koagulasi serta mengurangi aktivitas antikoagulasi pada sistem hemostasis (sumber). Perubahan tersebut dapat menyebabkan penderita Diabetes Mellitus tipe II berada dalam keadaan yang disebut dengan hiperkoagulasi. ${ }^{7}$ Dalam berbagai penelitian pada penderita Diabetes Mellitus tipe II sudah diketahui bahwa perubahan daya beku darah menjadi salah satu faktor utama yang berperan dalam patofisiologi terjadinya trombosis. Darah yang sudah mengalami hiperkoagulasi cenderung lebih mudah membeku bila mendapat stimulus koagulasi dan bekuan yang terbentuk akan lebih sulit untuk dilarutkan. Pada penderita Diabetes Mellitus tipe II terdapat keadaan dimana hiperkoagulasi yang disebabkan oleh hiperinsulinemia, hiperglikemia, dan resistensi insulin dapat memicu terjadinya perubahan pada komponen - komponen yang berperan dalam faal hemostasis. ${ }^{7}$ Faal hemostasis adalah suatu fungsi tubuh yang bertujuan untuk mempertahankan keenceran darah sehingga darah tetap mengalir dalam pembuluh darah dan menutup kerusakan pada dinding pembuluh darah sehingga mengurangi kehilangan darah pada saat terjadinya kerusakan pembuluh darah.

Berkaitan dengan berbagai permasalahan yang dipaparkan di atas, maka peneliti tertarik untuk mengetahui lebih lanjut tentang gambaran hasil pemeriksaan faal hemostasis pada penderita DM-2 di RSUP Sanglah, Bali, Indonesia

\section{METODE PENELITIAN}

Penelitian dengan desain potong lintang dilakukan terhadap 28 data sekunder (rekam medis) pasien dengan DM-2 yang menjalani pengobatan di RSUP Sanglah, Bali, Indonesia selama 1 Januari - 31 Desember 2015. Pemilihan rekam medis dilakukan secara konsekutif (consecutive sampling)/ Kriteria inklusi pada studi ini adalah seluruh pasien DM-2 yang melakukan tes laboratorium Faal Hemostasis. Sedangkan kriteria eksklusi adalah data rekam medis pasien yang tidak lengkap. Adapun beberapa variabel penelitian yang diteliti pada studi ini adalah: usia $\geq 40$ tahun, aktivitas fisik, obesitas, memiliki riwayat hipertensi, merokok, maupun kelengkapan data rekam medis meliputi hasil pemeriksaan prothrombin (PT), activated partial thromboplastin time (APTT), serta bleeding time (BT).

Data yang telah dikumpulkan kemudian diolah dengan menggunakan komputer melalui program SPSS versi 17 , data dianalisa secara deskriptif kemudian hasilnya akan ditampilkan dalam bentuk tabel atau narasi. Penelitian ini telah mendapatkan izin dan kelayakan untuk melaksanakan penelitian dari Komisi Etik Fakultas Kedokteran Universitas Udayana, untuk melakukan penelitian di Bagian Rekam Medis Rumah Sakit Umum Pusat Sanglah.

\section{HASIL}

Berdasarkan penelitian yang telah dilakukan diperoleh 28 sampel dengan hasil yang menunjukkan bahwa jumlah pasien laki - laki lebih mendominasi jika dibandingkan dengan perempuan. Jumlah laki - laki sebanyak 15 orang (53.6\%) sedangkan jumlah pasien perempuan 13 orang (46.4\%) (Tabel 1).

Tabel 1 juga menunjukkan bahwa pasien yang terdiagnosis Diabetes Mellitus tipe II memiliki rentang umur yang bervariasi. Dimulai dari rentang umur 40 - 50 tahun terdapat 7 orang (25\%), rentang umur 51 - 60 tahun terdapat 11 orang (39.3\%), rentang umur $61-70$ tahun terdapat 5 orang (17.9\%), 
Tabel 1 Karakteristik demografis responden Penelitian

\begin{tabular}{|c|c|c|}
\hline Parameter & $\mathbf{N}$ & Persentase (\%) \\
\hline \multicolumn{3}{|l|}{ Jenis Kelamin } \\
\hline Laki-Laki & 15 & $53,6 \%$ \\
\hline Perempuan & 13 & $46,4 \%$ \\
\hline \multicolumn{3}{|l|}{ Usia } \\
\hline 40-50 tahun & 7 & $25,0 \%$ \\
\hline 51-60 tahun & 11 & $39,3 \%$ \\
\hline $61-70$ tahun & 5 & $17,9 \%$ \\
\hline 71-80 tahun & 5 & $17,9 \%$ \\
\hline \multicolumn{3}{|c|}{ Riwayat Kesehatan } \\
\hline Hipertensi & 23 & $82,1 \%$ \\
\hline Merokok & 5 & $17,9 \%$ \\
\hline \multicolumn{3}{|c|}{ Waktu Protrombin $(\mathrm{PT})$} \\
\hline$>14$ detik & 7 & $25,0 \%$ \\
\hline $10-14$ detik & 19 & $67,9 \%$ \\
\hline$<10$ detik & 2 & $7,1 \%$ \\
\hline \multicolumn{3}{|c|}{$\begin{array}{l}\text { Waktu Tromboplastin Teraktivasi } \\
\text { Parsial (APTT) }\end{array}$} \\
\hline$>40$ detik & 5 & $17,9 \%$ \\
\hline $30-40$ detik & 15 & $53,5 \%$ \\
\hline$<30$ detik & 8 & $28,6 \%$ \\
\hline \multicolumn{3}{|c|}{ Waktu Pendarahan (BT) } \\
\hline$>1.30$ menit & 19 & $67.9 \%$ \\
\hline$<1.30$ menit & 9 & $32.1 \%$ \\
\hline
\end{tabular}

dan rentang umur $71-80$ tahun terdapat 5 orang (17.9\%). Rentang umur $51-60$ tahun merupakan rentang umur dengan distribusi pasien terbanyak dibandingkan rentang umur yang lainnya.

Distribusi riwayat peyakit pasien yang mengalami Diabetes Mellitus Tipe II dengan juga menunjukkan terdapat kasus hipertensi sebanyak 23 orang $(82.1 \%)$ dan dengan riwayat obesitas serta merokok sebanyak 5 orang (17.9\%) (Tabel 1).

Berdasarkan Tabel 1 dapat dilihat bahwa distribusi waktu pemeriksaan prothrombin (PT) yang melebihi waktu 14 detik sebanyak 7 orang (25\%), waktu yang sama dengan 10 - 14 detik sebanyak 19 orang (67,9\%), dan waktu yang kurang dari 10 detik sebanyak 2 orang (7.1\%). Hasil pemeriksaan Prothrombin Time pada sampel penelitian ini adalah 8,9-20,2 detik, dimana normal waktu pemeriksaan Prothrombin Time berkisar antara 10 - 14 detik.

Distribusi waktu pemeriksaan Activated Partial Thromboplastin Time (APTT) yang melebihi waktu 40 detik sebanyak 5 orang (17.9\%), waktu yang sama dengan 30 - 40 detik sebanyak 15 orang (53.5\%), dan waktu yang kurang dari 30 detik sebanyak 8 orang $(28.6 \%)$. Hasil pemeriksaan APTT pada sampel penelitian ini adalah 21,0 - 48,2 detik, dimana normal waktu pemeriksaan Activated Partial Thromboplastin Time (APTT) berkisar antara 30 - 40 detik (Tabel 1).

Tabel 1 menunjukkan bahwa pemeriksaan Bleeding Time (BT) yang melebihi waktu 1.30 menit terdapat sebanyak 19 orang $(67.9 \%)$ dan waktu yang kurang dari 1.30 menit sebanyak 9 orang (32.1\%). Hasil pemeriksaan Bleeding Time pada sampel penelitian ini adalah 0,5-2 menit, dimana waktu normal Bleeding Time berkisar antara 3-6 menit.

\section{PEMBAHASAN}

Analisis data terkait hasil pemeriksaan Faal Hemostasis pada pasien Diabetes Mellitus Tipe II berdasarkan rekam medis di RSUP Sanglah Denpasar dari Januari sampai Desember 2015 menunjukkan bahwa berdasarkan jenis kelamin, pasien dengan jenis kelamin laki - laki terbanyak terkait kasus Diabetes Mellitus Tipe II yaitu sebesar 53,6\%. Hasil ini juga sejalan dengan penelitian Nadyah Awad et al dimana jenis kelamin terbanyak pada kasus Diabetes Mellitus Tipe II adalah laki laki, yaitu sebesar $53 \%{ }^{8}$

Berdasarkan kategori umur, pasien dengan rentang umur 51 hingga 60 tahun yang tersering menderita penyakit Diabetes Mellitus Tipe II yaitu sebanyak 39,3\%. Hasil ini juga sejalan dengan penelitian yang dilakukan oleh Yuanita A. Langi et al dimana ditemukan puncak umur kejadian Diabetes Mellitus Tipe II yaitu pada umur 51 hingga 60 tahun menjadi kategori usia yang paling sering menderita penyakit Diabetes Mellitus Tipe II sebesar $41,30 \%{ }^{9}$

Berdasarkan distribusi waktu pemeriksaan prothrombin, pasien yang memiliki rentang waktu antara 10 - 14 detik paling banyak sebesar 67.9\%. Untuk waktu pemeriksaan activated partial thromboplastin time yang memiliki rentang waktu pemeriksaan 30 - 40 detik terbanyak, yaitu sebesar $53,5 \%$. Berdasarkan distribusi waktu pemeriksaan bleeding time yang melebihi 1.30 menit sebanyak $67,9 \%$. Hasil ini juga sejalan dengan penelitian yang dilakukan oleh Euis Mayangsari et al. dimana waktu pemeriksaan bleeding time melebihi 2 menit sebanyak $75 \% .^{10}$

Berdasarkan riwayat penyakit, pasien dengan riwayat hipertensi paling banyak sebesar $82,1 \%$. Hasil yang sama juga didapatkan pada penelitian yang dilakukan oleh Yuanita A. ${ }^{9}$ Akan tetapi studi yang dilakukan oleh Langi dkk menunjukkan riwayat hipertensi paling banyak yang menyebabkan diabetes mellitus tipe II hanya sebesar sebesar $57,1 \%$. Perbedaan hasil yang diperoleh tidak terlepas dari kelemahan penelitian yang meliputi penggunaan data sekunder yang diambil dari 
rekam medis sehingga mengakibatkan adanya keterbatasan dalam pengelolaan variabel perancu, jumlah sampel yang digunakan masih terbatas, dan terdapat faktor - faktor lain yang tidak diteliti yang mungkin akan mempengaruhi hasil penelitian. ${ }^{9}$

\section{SIMPULAN}

Dari hasil penelitian terhadap gambaran hasil pemeriksaan faal hemostasis pada penderita DM-2 di RSUP Sanglah Denpasar tahun 2015, maka dapat diambil simpulan sebagai berikut: Rata rata umur penderita DM-2 umur 51 - 60 tahun dimana jenis kelamin terbanyak adalah laki - laki. Riwayat penyakit DM-2 paling banyak adalah dengan riwayat hipertensi. Sedangkan pada pemeriksaan faal hemostasis waktu protrombin paling banyak pada 10 - 14 detik, diikuti dengan waktu tromboplastin teraktivasi parsial (APTT) berkisar antara 30 - 40 detik, maupun waktu pendarahan pada dengan waktu $>1.30$ menit pada pasien yang menderita DM-2.

\section{ETIKA PENELITIAN}

Studi ini telah mendapat persetujuan etik oleh komisi etik Fakultas Kedokteran Universitas Udayana sebelum studi dilakukan.

\section{KONFLIK KEPENTINGAN}

Tidak terdapat konflik kepentingan dalam penulisan artikel ini.

\section{PENDANAAN}

Penulis bertanggung jawab terhadap pendanaan penelitian secara mandiri.

\section{KONTRIBUSI PENULIS}

Seluruh penulis memiliki kontribusi yang sama dalam penyusunan laporan akhir penelitian pada artikel ini

\section{DAFTAR PUSTAKA}

1. Barclay A, Gilbertson H, Marsh K, Smart C. Dietary management in diabetes. Aust Fam Physician. 2010; 39(8):579-83.

2. Kharroubi AT, Darwish HM. Diabetes mellitus: The epidemic of the century. World J Diabetes. 2015 Jun 25;6(6):850-67

3. Forouhi NG, Wareham NJ. Epidemiology of diabetes. Medicine (Abingdon). 2014; 42(12): 698-702.

4. Mihardja L, Soetrisno U, Soegondo S. Prevalence and clinical profile of diabetes mellitus in productive aged urban Indonesians. J Diabetes Investig. 2014;5(5):507-12.

5. Garry-Webb TL, Suglia SF, Tehranifar P. Social Epidemiology of Diabetes and Associated Conditions. Curr Diab Rep. 2013; 13(6):850-859.

6. Tapp RJ, Shaw JE, Harper CA et al. The prevalence of and factors associated with diabetic retinopathy in the Australian population. Diabetes Care. 2003 ;26(6):1731-7.

7. Carr ME. Diabetes mellitus: a hypercoagulable state. J Diabetes Complications. 2001 ;15(1):44-54.

8. Awad N, Langi YA, Pandelaki K. Gambaran faktor resiko pasien diabetes melitus tipe II di poliklinik endokrin Bagian/SMF FK-Unsrat RSU Prof. Dr. R.D Kandou Manado Periode Mei 2011 - Oktober 2011. Jurnal e-Biomedik (eBM). 2013; 1(1):45-49.

9. Langi YA. Penatalaksanaan ulkus kaki diabetes secara terpadu. Jurnal Biomedik. 2011; 3(2):95-101

10. Mayangsari E, Octaviana EW, Farihatun A. Gambaran hasil pemeriksaan bleeding time (waktu perdarahan) dengan metode IVY dan DUKE. Jurnal Stikes Muhammadiyah Ciamis. [Skripsi]. 2016: 1-24

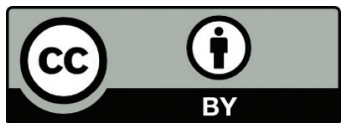

This work is licensed under a Creative Commons Attribution 